\title{
Transnational migration and educational opportunities: A case study of migration from Brazil to Germany
}

\author{
Javier A. Carnicer* - University of Münster, Germany
}

\begin{abstract}
Based on a case study, this article discusses connections between educational inequality in Brazil, transnational migration and educational upward mobility. It analyses a young woman's migration from a favela in Brazil to Germany with a focus on the educational aspirations that motivated it, that is, as a case of educational migration. It describes the social trajectories of this young woman and her family and interprets them in the context of recent socio-economic developments in Brazil, thus showing how educational inequality can drive migration. The significance of networks, as well as of migration and educational regimes that shape this trajectory, are taken into account. The analysis aims to show how migrants from disadvantaged social backgrounds actively take part in the transnationalization of education.
\end{abstract}

Keywords: Transnational migration; care work migration; educational inequality; transnational education

Luciana grew up in a favela in a big city in the south-east of Brazil. At the age of 19, she came to Germany as an au pair. After one year, she prolonged her au pair stay and applied for a voluntary social year in a retirement home. There, she began to train as a geriatric nurse. As soon as the three years of apprenticeship are over, it is very likely that Luciana will get a position at the same retirement home and obtain a long-term residence permit.

Cases such as Luciana's have gained attention in migration studies as part of the international feminization of migration due to the 'care crisis' (Fraser, 2016) that affects the richest countries of the world, including Germany (Fürstenau, 2018). But, at the same time, Luciana's case offers particularities that are seldom focused on by migration research: she migrated not to find better work, but to study at a university in Germany. While this is a plan yet to be realized, Luciana's activities in Germany constantly aim at expanding her education, first, by exploring the possibilities of accessing university and learning the language to the high standard required for both university and dual vocational training, and then through the training itself.

In the following pages, I analyse Luciana's migration focusing on the educational aspirations that motivated it, hence, as a case of educational migration. The analysis is part of an ongoing research project about transnational education and social positioning between Brazil and Europe. The study is being conducted together with Sara Fürstenau (University of Hamburg) and is funded by the German Research Foundation (DFG). This project investigates the connections between migration decisions, educational strategies and transnational family organization in different social contexts. First findings demonstrate how educational opportunities influence 
the migration decisions of young people and families. This refers not only to socially privileged groups who possess the resources to access a global education market, but also to underprivileged youths such as Luciana, for whom migration constitutes a strategy of educational upward mobility (Carnicer, 2018; Fürstenau, 2018). The emergence of such aspirations is remarkable in social settings such as Luciana's favela, where comparable experiences are absent and appropriate resources such as foreign language skills, internationally recognized school certificates and even money are lacking. Based on a detailed reconstruction of Luciana's educational and migration trajectory, this article analyses how such transnational educational aspirations are developed and realized. The results depict how migrants from disadvantaged social backgrounds actively take part in the transnationalization of education.

After briefly outlining the conceptual framework of the study and its research context, I describe the procedure for the case study. The analysis aims to reconstruct the educational aspirations of Luciana, as well as her educational experiences and strategies. The social conditions and trajectories of Luciana's family are described and interpreted in the context of recent socio-economic developments in Brazil. Both provide the background to understand Luciana's emigration as a strategy of educational upward mobility. Drawing on the case study of Luciana, I will finally discuss how educational inequality can drive migration and how specific networks as well as migration and educational regimes shape the corresponding trajectories.

\section{Transnational education and migration}

Terms such as transnational education and transnational educational spaces appear increasingly in the research literature, reflecting the ways in which education is affected by processes that transcend national borders and cannot solely be understood within the framework of the national educational systems. The use of these terms implies a rupture with the 'methodological nationalism' that undermined an important part of the social sciences (Wimmer and Glick Schiller, 2003). Yet the meaning of these terms varies according to the research context and is sometimes vague. Transnational educational spaces can be read as an analogy to the term transnational social spaces that was coined by migration research at the end of the 1990s (Faist, 2000; Levitt and Glick Schiller, 2004; Pries, 1996). The transnational perspective arose in migration research as an attempt to understand 'the processes by which immigrants forge and sustain multistranded social relations that link together their societies of origin and settlement' (Basch et al., 1994: 8). In parallel with discourses about globalization that tend to emphasize the role of big corporations, transnational migration research focuses on the social practices of migrants and non-mobile persons as important contributions to the 'transnationalization of the social world' (Pries, 2008). In this research context, social practices in the field of education seldom feature as a subject of analysis, although it may be assumed that education plays an important role in the consolidation of social structures such as transnational social spaces. In turn, a transnational perspective is still new to educational research. Studies in the field of transnational education (TNE) interpret this term in accordance with the United Nations Educational, Scientific and Cultural Organization (UNESCO) definition as 'the mobility of education programs and providers between countries' (Knight, 2016; UNESCO and Council of Europe, 2001). They focus mainly on higher education, with some interest in private international schools. The institutions and offerings in this area can be seen as part of a globalized education market, primarily accessible to socially and economically privileged groups (Adick, 2005; Hayden, 2011). The related international student mobility has begun to 
be examined through the lens of transnational migration research only in recent years (Brooks and Waters, 2011; Gargano, 2009; King and Findlay, 2012; King and Raghuram, 2013; Waters and Brooks, 2012). These studies point to the increased importance of transnational educational strategies among the middle classes, showing that studying abroad is not necessarily just the privilege of social elites. Below the middle classes, however, we know little about the ways in which educational aspirations and strategies influence families' and young people's decisions to migrate and their impact on transnational social spaces. Aside from individual studies, non-elite migrants are not seen as potential beneficiaries of TNE (Fürstenau, 2015b: 74). This implies that migration is considered to be an educational strategy only in privileged contexts above the lower middle classes.

\section{Education and emigration in Brazil}

The migration flows between Brazil and Europe are of particular relevance for our research because of the diversity of the underlying social conditions. Since the 1980s, poverty and social inequality in Brazilian society have been important reasons for emigration, but the labour migration of professionals from social elites is also prevalent (Evans et al., 2013). In 2014, approximately 27 per cent of all migrants from Brazil lived in Europe (Ministério das Relações Exteriores, 2015). In Germany, Brazilian immigration is highly feminized: 75 per cent of registered Brazilian migrants are women (Stelzig, 2008: 6). This may be because of the increased demand for labour in the service sector, particularly in care work.

The inequality between rich and poor in Brazil is among the world's greatest, and the poverty rate is high. About 25 per cent of the population has to live on less than US $\$ 5.5$ a day. Forty-three and a half per cent of those who fall below this poverty line live in the north-east, 12.3 per cent in the south, and about 16 per cent in the region examined in this article (data from 2017 according to IBGE, 2017: 63). Between 2000 and 2014, poverty decreased considerably owing to economic expansion and redistributive policies such as Bolsa Família, a monthly cash grant to women whose children were vaccinated and attended school. During this time, wages and formal employment rose. This contributed to a growth in the purchasing power of the poor, as well as to an improvement in working conditions and social protection, especially with regard to health insurance. Families who were struggling to meet basic needs improved not only their access to health care and education, but also to consumer goods such as televisions, cellphones and computers. An enormous segment of the better situated poor was pulled into a much celebrated 'new middle class' (Neri, 2011), corresponding to the 'Class $C^{\prime}$ of the Brazilian Institute of Geography and Statistics (IBGE). The IBGE differentiates five classes (A, B, C, D, E) according to income. Persons earning between $R \$ 3,748.01$ and $R \$ 9,370.00$ are considered to be in class $C$, which is, indeed, the middle between A, B and D, E. To speak of a middle class seems overstated, however, since the income of the lower part of this economic fraction lies near the poverty line of US $\$ 5.5$ per day. Even wealthier members of Class $C$ have no access to the privileges of the typical middle class: they have to work from a very young age, with very long work days combined with small jobs over the weekend. If they manage to access higher education, it is in private universities of lower quality than the public universities. Because of the precarious conditions, it seems more appropriate to speak of a 'new working class', as some Brazilian sociologists have suggested (Pochmann, 2015; Souza and Arenari, 2012). Yet, although the many simplifications and reductions of 'official' and dominant accounts ought to be questioned, the underlying social 
processes resulted in the impressive social ascent of whole underprivileged classes. Sadly, the positions attained were not stable. With the economic recession after 2014 and the cuts in public expenditures since then, many of those who made it into Class $C$ have already returned to their impoverished conditions of 15 years ago (Costa, 2018).

Social inequality in Brazil is reinforced by an educational system paradoxically divided between the public and the private sector. For graduates of public schools, it is very difficult to obtain a place in one of the public, tuition-free universities. Graduates of expensive private schools have clear advantages, as they are better prepared to pass the entrance examinations (Pfeiffer, 2015). Policies intended to facilitate access for black and mixed-race students have contributed to an increase in the number of students from disadvantaged backgrounds studying at public universities, yet extreme educational inequality prevails (Nierotka and Trevisol, 2016).

Additionally, in Brazil, as in other countries, educational expansion since the end of the twentieth century has driven privileged groups to new ways of legitimizing social privilege through education. Skills such as fluency in English and other foreign languages, experiences and studies abroad, as well as the corresponding certificates constitute a cultural capital that helps to attain or legitimize privileged positions. This capital is very difficult to acquire in public schools (Aguiar and Nogueira, 2012; Almeida, 2015). In this way, the internationalization of education contributes to a 'redefinition of educational advantage' (van Zanten et al., 2015), since access to these institutions requires resources that only socially privileged families possess.

My own ongoing research has revealed that educational opportunities and especially the opportunity to access higher education play an important role in the migration decisions of young Brazilians in Germany who come from social conditions well below the middle classes. Most of the interviewed migrants attended public schools in Brazil and did not have the economic resources and the cultural capital (such as certificates and language skills) required to access university in Germany. This lack of resources has to be compensated for through informal support structures and by adopting migration strategies that in many cases conflict with educational plans. Even if not all of them managed to study at a university in Germany (as most of them initially intended), their migration has to be seen as an educational strategy. This strategy is striking, since it is based on the estimation that the German educational system can provide better educational opportunities for them than the Brazilian system, even if it requires the acquisition of additional education certificates and of German language skills at a very high level. The study of individual cases such as Luciana's allows us to understand how such transnational educational orientations emerge, as well as allowing us to grasp the ways in which they are pursued (Carnicer, 2018, 2016; Fürstenau, 2018, 2015a).

\section{Methods}

Following a multisited ethnographical approach (Marcus, 1995), our project collects data at different locations in Germany and Brazil as well as in different social fields: the sample includes migrants in search of a 'better life' as well as members of transnational social elites. In line with the ethnographical approach, we use different methods: participant observation, guided and narrative interviews, ego-centred network analysis and compilation of family trees (Carnicer, 2018). The research follows the 'networks of people linked to each other across national boundaries' (Mazzucato, 2008: 72), which are the unit of analysis. Individual cases are analysed not only on the basis of individual narratives, but also in the context of relevant social networks and institutions 
(especially schools). The work presented in this article follows the logic of a case study (the trajectory of Luciana) and is only one part of the research that examines a much broader transnational social network (Fürstenau, 2018). The empirical corpus related to Luciana's case consists of about 16 interviews with her and persons related to her, as well as informal conversations and participant observations in her neighbourhood of origin in Brazil and in the city where she lives in Germany. The main sources for the analysis presented here are the in-depth interviews with Luciana, her parents and her two sisters, which were conducted at different places in Germany and Brazil between 2015 and 2017. I thank Sara Fürstenau (University of Hamburg) for providing the data and for her cues regarding its interpretation. The interviewees were asked to describe their life course and to talk about their own as well as their family's educational experiences, strategies and orientations. The interviews were conducted, transcribed and analysed in Portuguese. After an initial comparison of various individual trajectories, Luciana's case was selected for deeper analysis for diverse reasons: Luciana grew up in a low-income neighbourhood and her migration was clearly driven by her high educational aspirations. However, as will be explained below, Luciana's educational background seems to put her in a good position to access university in Brazil, whereas her lack of resources renders studying abroad an enterprise with uncertain outcomes. Moreover, Luciana could not count on the advice and support of a transnational social network at the outset. On the contrary, her support network was built during migration. My colleague Sara Fürstenau (2018) analysed this network in greater detail. This article focuses on an analysis of Luciana's educational and migration trajectory. The in-depth study of the interviews with Luciana and her family aims not only at capturing her individual trajectory with its guiding orientations and strategies, but also at reconstructing the underlying social conditions as perceived and interpreted by the interviewees themselves, since these constitute the breeding ground for their aspirations and projects. In this way, the analysis contributes to understanding how educational disadvantages influence migration decisions.

The summary of the case presented on the following pages begins with biographical information about Luciana and her parents' educational experiences. Thereafter, I describe Luciana's educational trajectory in Brazil, depicting how it shaped her experiences of social exclusion - which I interpret to be the basis of her migration project. After reconstructing her course of migration, I close with a discussion about the ways in which educational inequality, care work regimes and social networks can drive educational migration.

\section{Case study}

Luciana grew up in a favela in south-eastern Brazil, which we will call Campo Roxo. She is the eldest of Angela and Nelson's three daughters. Angela, Luciana's mother, came from the north-east of Brazil when she was ten years old - five years after her own mother, who came to work as a housemaid in one of the rich neighbourhoods surrounding Campo Roxo. With an estimated population between 70,000 and 120,000, Campo Roxo is one of the largest favelas in Brazil. Favelas are an urban phenomenon typical of Rio de Janeiro and other Brazilian cities. They were originally territories occupied by settlers who did not own the land and mostly lived in precarious, selfconstructed homes. In the 1930s, Campo Roxo was a settlement of small-scale farmers. A few years later, it was reached by the city and surrounded by affluent urban neighbourhoods. Campo Roxo mutated into a city within the city, housing the janitors, domestic servants, clerks and other poor workers of its rich neighbourhoods and 
attracting migrants from poorer regions in the interior and the north-east of Brazil, such as Angela's mother.

Angela laments that she did not enjoy appropriate conditions for her childhood development, as she lacked not only 'peace at home', but also decent meals and a suitable place to sleep. At the age of 16, she ran away with Nelson. Two years later, Luciana was born.

The educational trajectories of Luciana's parents differ greatly. While Angela left school after seventh grade, Nelson graduated with a Masters in Business Administration (MBA) from a prestigious private university - after many detours and with the support of his wife and various sponsors. Nelson was born and raised in Campo Roxo, and went to a public municipal school in a neighbourhood near the favela. At the age of 11, he started to contribute to the family income as a newsboy, attending school in the evening. Always working and with some interruptions, Nelson completed secondary school at the age of 21 . Two years later, he began to study at a private university, but soon he had to suspend his studies because he could not afford the fees. Five years later, with the economic support of a religious organization and a private sponsor, he was able to resume his studies and to graduate. Thereafter, supported by the same sponsors, Nelson also managed to do an MBA at the local Pontifical Catholic University (PUC). The PUC is a private and renowned university that competes with the better public federal universities and, despite its expensive fees, is usually preferred by wealthier families.

Nelson's career is very unusual in the favela, but not unique. Affirmative action policies, non-governmental organizations offering courses to prepare low-income high school graduates for the university entrance exams (pré-vestibulares comunitários) as well as grants from public and private organizations have certainly contributed to an increase in the modest number of favela residents who attend university (Valladares, 2010). Even with grants, however, the vast majority of these students have to work to earn a living during their studies (ibid.). Such was the case for Nelson, father of three, who depended on odd jobs for unskilled workers most of the time. The main contributor to the family's income was Angela, his wife, who worked mostly as a cleaner, domestic servant and nanny. She backed Nelson, freeing him from the obligation to take jobs that would conflict with his study schedule. Nelson's educational advancement clearly constitutes a joint project for the couple, a long-term strategy to improve the family's living conditions. The course of this project clearly illustrates some of the barriers that prevent poor and working-class people from accessing social wealth in Brazil, even at a time of economic advancement.

One of these barriers stems from a form of discrimination whose primary trigger is a combination of colour, class and place. I speak of colour because racism in Brazilian society is based more on skin colour than on ancestry (Telles, 2006). Thus, a single family can have children of different racial categories. Skin colour was a recurrent topic in the interviews with both of Luciana's parents, who speak of themselves as black. The issue of discrimination is very explicitly addressed by Nelson, whose most blatant account corresponds to his experiences at the PUC:

In all the places that I passed, there was always some repudiation. Because of the colour, or because of the social class. But I've always been able to break down barriers and get close to people. At the PUC, it was more difficult.

Nelson claims the ubiquity of repudiation triggered by skin colour and social class. Later, he explains that he always gave an address outside the favela when being asked 
about his residence. This is a common and well-known practice to avoid rejection (Robb Larkins, 2015: 200), since an address in the favela is a marker for exclusion. To live in the favela was at first associated with poor sanitation and illness; nowadays, criminality is superimposed on this simplification of the identities and living conditions within the favelas. These different markers appear to be interchangeable, however, and the words for poor (pobre), black (preto, negro), favela resident (favelado) and criminal (bandido) very often function as synonyms (Ystanes, 2018: 90; Valladares, 2008: 21; Perlman, 2010).

Nelson says that, although it was difficult, he managed to be accepted by his fellow students at the PUC, whom he describes as entrepreneurs and executives from the social elite. These relationships could have been an asset for Nelson's career. But asked about current contact with them, he speaks only about one, who was able to study there because he was the son of an employee. Nelson seems to be ambivalent about the value of his MBA from one of the most renowned universities. He says that his qualification seems rather to be his 'enemy', because he is now 'overqualified': 'Now, when I look for a position in the labour market, often the person who will hire me is less qualified than I.'

'Overqualification' appears to be a problem related to the stigma of living in a favela, however. Pero et al. (2005) and Perlman (2010) show that the return to education is lower for favelados than for non-favelados, with an income gap that increases with years of education. This gap reflects the difficulties of favela residents to get jobs (and pay) according to their qualifications. Only after a long job search did Nelson find a position as administrative assistant, well below his potential level. Later he was promoted, and Angela could reduce her workday to a few hours per week. After six years, however, Nelson's company went bankrupt and he lost his job.

Nelson's trajectory reflects the couple's high educational aspirations as well as their firm, but disillusioned, belief in the importance of education and individual achievement for their social advancement.

\section{Luciana's educational trajectory in Brazil}

Luciana was 14 when her father graduated and was looking for a job. Her educational career, like her father's, seems unusual for a child of the favela. Until the age of 12 , she attended a municipal school in one of the richer neighbourhoods surrounding Campo Roxo. But then, first through her mother's job, then with grants, she had opportunities to attend some of the better private schools. Luciana's mother worked for some time as a school nanny. In Brazil, private schools are obliged to grant scholarships for the children of their employees, regardless of position and fees. In this case however, Luciana had to pass an entrance examination. Additionally, some private schools offer grants for low-income families based on the children's school performance, which is mostly assessed through examinations. Of these schools, Luciana reports contradictory experiences. On the one hand, she received better educational provision and socialized well with other children at the school. This is remarkable because of the blatant differences in wealth. Luciana tells that her friends had houses with swimming pools and that they spent their holidays abroad, whereas she dreamed of a house with painted walls. On the other hand, she was bullied because she was perceived as black, and she was treated badly by hall monitors and other employees who thought that, being the daughter of an employee, she should not behave like the other students. Her parents admit that Luciana 'suffered a little' during this time, and their narrative of her experiences in the private school sounds as if she underwent a difficult and painful learning process about her own social position. 
Nelson says that at first 'she was convinced she was white' and only after some time 'she began to understand that she was from a different social class'. Paradoxically, Luciana's inclusion in the privileged schools makes visible her exclusion as favelada. Prejudices and bullying are a violent practice of othering, but according to Nelson, Luciana experienced the social differences even in relations with her friends. She was faced with direct exclusion as well, since the scholarships did not cover the often very expensive school excursions and other extracurricular activities. Luciana's learning about social differences appears to have deepened when she had to move to a public school for some months. About this school, she says: 'There I saw that in the public school the teachers did not teach, there were no books, they had nothing and I did not want to. I never wanted to live the life I lived in Brazil.'

In parallel with these experiences, Luciana perceived that her father's successful educational career did not lead to corresponding social advancement. In this way, Luciana gained an embodied understanding of inequality in Brazil. Her educational career strengthened her high aspirations, but at the same time, showed her that, in her position, upward social mobility requires something more than educational success.

\section{Luciana's migration}

Having completed secondary school, Luciana passed the university entrance examinations (ENEM) without problems. She thought, however, it would be difficult to finance her studies, even without having to pay fees. Lacking alternatives, she worked for some months as a secretary, gave private lessons for children and attended an English course outside Campo Roxo. There she met a woman whose daughter was living in Germany and was looking for a Brazilian au pair. This daughter would provide accommodation and pay for the flight to Europe, as well as for German lessons. Luciana accepted, insisting that her goal was to study in Germany. In 2012, at the age of 19, she travelled to Germany. She was not only the first in her family to emigrate abroad, but also, as far as she or her family are aware, the first of her neighbourhood in Campo Roxo.

German universities are tuition free for the most part, but academic and visa requirements are intertwined. A specific visa permit is required to study in Germany. Being admitted to university or vocational training can, in turn, lead to a longer residence permit. Both require a financial guarantee. But to enter university, graduates of a Brazilian high school need to attend a one-year foundation course at a Studienkolleg first and then pass the university entrance examination. For the Studienkolleg, there is an entrance examination as well. Both exams and, of course, the studies themselves demand a high level of skill in the German language.

After a year in Germany, Luciana tried to pass the entrance exam for the Studienkolleg, but she did not succeed. She wanted to stay longer to improve her German skills and try the exam again. In the meantime, she had met other young women from Brazil who had come to the country under similar conditions and, like her, were looking for educational opportunities. One of them referred her to another host family, so that she could extend her stay as an au pair. Another, called Daiane, had also immigrated as an au pair as well. After a year, Daiane had undertaken a voluntary year, a Freiwilliges Soziales Jahr (FSJ) in a residential care home for the elderly and was now doing a three-year apprenticeship as a geriatric nurse in the same care home. Luciana took the same path. After her second year in Germany, she obtained another 12 -month visa for a voluntary year and received 380 euros a month. After seven months, she applied for an apprenticeship as a geriatric nurse, like Daiane, and was accepted. This career path, opened by Daiane and then followed by Luciana, constitutes a 
strategy that is now shared among friends and family, offering a proven way to migrate to Germany. Luciana now has a stay permit for three years and a modest salary. The apprenticeship includes a respectable amount of regular work as well as classes at vocational school. Although she originally wanted to study a social science discipline, Luciana finds her work very satisfying and declares she has developed an interest in psychiatry and medicine. Now she plans to work for a while after the vocational training is complete and to study medicine in Germany afterwards.

In the meantime, her father in Campo Roxo has lost his job and with it not only his income, but also health insurance for the whole family. A few months earlier, Anita, Luciana's younger sister, had been operated on for a difficult illness, and she now needs medication and regular medical observation. Without health insurance, both have become expensive and difficult to obtain. Additionally, Anita had completed secondary school and wanted to continue her education. Luciana, who was already often sending money to help her family, has now organized a voluntary year in Germany for her sister because of the health insurance that is included. Despite her low income, Luciana is paying for flights and German lessons, and is helping her sister to continue her education in Germany. In this way, Luciana's attempt to access higher education through migration has become a source of social protection for her family.

\section{Discussion}

Research into the educational upward mobility of migrants has often focused on the attainments of the so-called 'second generation', and the migration of underprivileged groups has seldom been considered to be educational migration. Cases such as Luciana's may be studied in the context of care work migration and the global care chains that link distant regions around the world. But to do so would not only fail to do justice to Luciana's projects and aspirations, but also would miss important dimensions (Fürstenau, 2018). Luciana's migration has to be interpreted in the context of the socioeconomic changes that Brazilian society has undergone during the last 15 years. The analysis of her trajectory as well as of her and her family's living conditions shows that social inequality and the failure of social protection provide a catalyst for migration. However, not these other factors, but educational inequality is the direct driver of migration. Economic development has awakened individual aspirations among the new working classes that can hardly be fulfilled in the unequal structures of Brazilian society, especially since the recession that began in 2014. For young people in Luciana's position, these include educational aspirations. Her migration can be seen as a means to attain educational opportunities from which she felt she was being excluded in Brazil. It constitutes an educational strategy that is not directed towards a symbolic capital that legitimates an inherited social position, but towards overcoming social exclusion.

Aspirations alone are not enough to trigger emigration in places as disadvantaged as favelas, however. Further structures are needed that enable the individuals to move. For Luciana, this structure arises from the 'care crisis' that affects the richest countries in the world (Fraser, 2016). The au pair programme has already been discussed in migration research as 'an immigration channel that facilitates the legal incorporation of "students" as care workers' (Isaksen, 2010: 12). Au pairing is commonly perceived as cultural exchange and not as work, despite the fact that many au pairs carry out the same tasks as domestic workers (Cox, 2014). Almost the same applies to the voluntary year in Germany, even in an area with acute labour shortages. In both cases, obtaining a visa permit is comparatively easy, since housing and a small salary are part of the 
arrangement. These programmes supply a demand for care workers on the edge between family or volunteering and work, and this demand is the niche that migrants like Luciana can use to open up opportunities for themselves. It must be noted that this is a gendered strategy, as care work is still constructed as a female domain (Lutz and Palenga-Möllenbeck, 2012).

Transnational educational careers of underprivileged migrants are influenced in a decisive way not only by migration regimes (for example, laws and regulations about legal entry and residence conditions), but also by the educational systems of emigration and immigration countries. Migration and education regimes intertwine to determine the possibilities of residence, study and work. The knowledge of these possibilities can be difficult to acquire and migrants often rely on advice to realize their plans. In most cases, this advice is supplied by social networks. These provide information about the available opportunities as well as support to allow their realization. In the case of Luciana, this network emerged during migration, and the course of her migration seems to have been pure chance - alongside her readiness to seize opportunities as they appeared. This is understandable, as the lack of resources also implies a lack of possibilities for planning. But this is not the case for her younger sister or others who came to Germany with the support of Luciana and Daiane. Their migration can be planned thoroughly. This is not only because of the material support offered by the network, but above all, because of its knowledge about the different formal and informal resources and possibilities. The network acts here as a structure that channels educational aspirations into transnational careers and contributes to an institutionalization of particular forms of educational migration.

Luciana's case shows that a lack of educational opportunities can drive the migration of young people from underprivileged social strata. Their scarce resources imply that their migration and life courses are much more reliant upon meeting visa requirements, working to finance their stay and supporting their families back home, than by their status as students or aspirants to higher education. This applies even to those who count on the support of social networks from the outset. In turn, being involved in such networks entails opportunities not accessible elsewhere. In this sense, transnational social networks constitute a factor of inequality as well.

\section{Notes on the contributor}

Javier A. Carnicer is Visiting Professor in intercultural education at the University of Münster. His work explores the implications of migration and social inequality for educational institutions and educational theory. His current research focuses on transnational social networks, migration and educational mobility between Brazil and Europe.

\section{References}

Adick, C. (2005) 'Transnationalisierung als Herausforderung für die International und Interkulturell Vergleichende Erziehungswissenschaft'. Tertium comparationis, 11 (2), 243-69.

Aguiar, A. and Nogueira, M.A. (2012) 'Internationalisation strategies of Brazilian private schools'. International Studies in Sociology of Education, 22 (4), 353-68.

Almeida, A.M.F. (2015) 'The changing strategies of social closure in elite education in Brazil'. In van Zanten, A., Ball, S.J. and Darchy-Koechlin, B. (eds) World Yearbook of Education 2015: Elites, privilege and excellence: The national and global redefinition of educational advantage. London: Routledge, 71-81. 
Basch, L., Glick Schiller, N. and Szanton Blanc, C. (1994) Nations Unbound: Transnational projects, postcolonial predicaments, and deterritorialized nation-states. Langhorne, PA: Gordon and Breach.

Brooks, R. and Waters, J. (2011) Student Mobilities, Migration and the Internationalization of Higher Education. Basingstoke: Palgrave Macmillan.

Carnicer, J.A. (2016) 'Multilinguismo e educação em famílias transnacionais entre o Brasil e a Alemanha'. In Bahia, J. and Santos, M. (eds) Um olhar sobre as diferenças: A interface entre projetos educativos e migratórios. São Leopoldo: Oikos, 18-34.

Carnicer, J.A. (2018) 'Transnational family and educational trajectories'. Transnational Social Review, 8 (2), 170-84.

Costa, S. (2018) 'Entangled inequalities, state, and social policies in contemporary Brazil'. In Ystanes, M. and Strønen, I.Å. (eds) The Social Life of Economic Inequalities in Contemporary Latin America: Decades of change. Cham: Palgrave Macmillan, 59-80.

Cox, R. (2014) 'Domestic workers and au pairs'. In Anderson, B. and Keith, M. (eds) Migration: The COMPAS anthology. Oxford: Centre on Migration, Policy and Society, 51-2.

Evans, Y., Tonhati, T. and Souza, A. (2013) Imigrantes Brasileiras pelo Mundo - Female Brazilian Migrants around the World. London: Grupo de Estudos sobre Brasileiros no Reino Unido, University of London.

Faist, T. (2000) 'Grenzen überschreiten: Das Konzept transstaatliche Räume und seine Anwendungen'. In Faist, T. (ed.) Transstaatliche Räume: Politik, Wirtschaft und Kultur in und zwischen Deutschland und der Türkei. Bielefeld: Transcript, 9-56.

Fraser, N. (2016) 'Contradictions of capital and care'. New Left Review, 100, 99-117.

Fürstenau, S. (2015a) 'Educação transnacional e posicionamento social entre o Brasil e a Europa: Um estudo qualitativo com famílias migrantes'. In Bahia, J. and Santos, M. (eds) Migraçoes, redes e trajétorias entre a Alemanha e o Brasil. Porto Alegre: Letra e Vida, 69-86.

Fürstenau, S. (2015b) 'Transmigration und transnationale Familien: Neue Perspektiven der Migrationsforschung als Herausforderung für die Schule'. In Leiprecht, R. and Steinbach, A. (eds) Schule in der Migrationsgesellschaft: Ein Handbuch, Bd. 1: Grundlagen - Diversität Fachdidaktiken. Schwalbach: Debus Pädagogik, 143-65.

Fürstenau, S. (2018) 'Educational aspirations of underprivileged female migrants: An ethnographic case study of a transnational network of care workers between Brazil and Germany'. Zeitschrift für Erziehungswissenschaft, in print.

Gargano, T. (2009) '(Re)conceptualizing international student mobility: The potential of transnational social fields'. Journal of Studies in International Education, 13 (3), 331-46.

Hayden, M. (2011) 'Transnational spaces of education: The growth of the international school sector'. Globalisation, Societies and Education, 9 (2), 211-24.

IBGE (Instituto Brasileiro de Geografia e Estatística) (2017) Síntese de Indicadores Sociais: Uma análise das condições de vida da população Brasileira: 2017. Rio de Janeiro: Instituto Brasileiro de Geografia e Estatística.

Isaksen, L.W. (2010) 'Introduction: Global care work in Nordic societies'. In Isaksen, L.W. (ed.) Global Care Work: Gender and migration in Nordic societies. Lund: Nordic Academic Press, 9-19.

King, R. and Findlay, A. (2012) 'Student migration'. In Martiniello, M. and Rath, J. (eds) An Introduction to International Migration Studies: European perspectives. Amsterdam: Amsterdam University Press, 259-80.

King, R. and Raghuram, P. (2013) 'International student migration: Mapping the field and new research agendas'. Population, Space and Place, 19 (2), 127-37.

Knight, J. (2016) 'Transnational education remodeled: Toward a common TNE framework and definitions'. Journal of Studies in International Education, 20 (1), 34-47.

Levitt, P. and Glick Schiller, N. (2004) 'Conceptualizing simultaneity: A transnational social field perspective on society'. International Migration Review, 38 (3), 1002-39.

Lutz, H. and Palenga-Möllenbeck, E. (2012) 'Care workers, care drain, and care chains: Reflections on care, migration, and citizenship'. Social Politics, 19 (1), 15-37.

Marcus, G.E. (1995) 'Ethnography in/of the world system: The emergence of multi-sited ethnography'. Annual Review of Anthropology, 24, 95-117.

Mazzucato, V. (2008) 'Simultaneity and networks in transnational migration: Lessons learned from an SMS methodology'. In DeWind, J. and Holdaway, J. (eds) Migration and Development within and across Borders: Research and policy perspectives on internal and international migration. Geneva: International Organization for Migration, 69-100.

Ministério das Relações Exteriores (2015) 'Brasileiros no mundo: Estimativas populacionais das comunidades'. Online. https://tinyurl.com/y8924v23 (accessed 19 November 2018). 
Neri, M. (2011) A nova classe média: O lado brilhante da base da pirâmide. São Paulo: Saraiva.

Nierotka, R.L. and Trevisol, J.V. (2016) 'Os jovens das camadas populares na universidade pública: Acesso e permanência'. Revista Katálysis, 19 (1), 22-32.

Perlman, J. (2010) Favela: Four decades of living on the edge in Rio de Janeiro. New York: Oxford University Press.

Pero, V., Cardoso, A. and Elias, P. (2005) 'Discriminação no mercado de trabalho: O caso dos moradores de favelas cariocas'. Coleção Estudos Cariocas, 5, Article 20050301, 1-18. Online. https://tinyurl.com/y78uofv8 (accessed 19 November 2018).

Pfeiffer, D.K. (2015) 'Das Bildungssystem Brasiliens unter besonderer Berücksichtigung des Hochschulwesens'. In Oelsner, V. and Richter, C. (eds) Bildung in Lateinamerika: Strukturen, Entwicklungen, Herausforderungen (Historisch-vergleichende Sozialisations- und Bildungsforschung 15). Münster: Waxmann, 78-97.

Pochmann, M. (2015) O mito da grande classe média: Capitalismo e estrutura social. São Paulo: Boitempo.

Pries, L. (1996) 'Transnationale soziale Räume: Theoretisch-empirische Skizze am Beispiel der Arbeitswanderungen Mexico-USA'. Zeitschrift für Soziologie, 25 (6), 456-72.

Pries, L. (2008) Die Transnationalisierung der sozialen Welt: Sozialräume jenseits von Nationalgesellschaften. Frankfurt am Main: Suhrkamp.

Robb Larkins, E. (2015) The Spectacular Favela: Violence in modern Brazil. Oakland: University of California Press.

Souza, J. and Arenari, B. (2012) Os batalhadores brasileiros: nova classe média ou nova classe trabalhadora? Humanitas, Belo Horizonte: Editora UFMG.

Stelzig, S. (2008) 'Länderprofil Brasilien'. Focus Migration, (15).

Telles, E.E. (2006) Race in Another America: The significance of skin color in Brazil. Princeton: Princeton University Press.

UNESCO and Council of Europe (2001) 'Code of Good Practice in the Provision of Transnational Education (adopted by the Lisbon Recognition Convention Committee at its second meeting, Riga, 6 June 2001)'. Online. https://tinyurl.com/ya2xjm6x (accessed 19 November 2018).

Valladares, L. (2008) 'Social science representations of favelas in Rio de Janeiro: A historical perspective'. LLILAS Visiting Resource Professor Papers, 1-31. Online. https://tinyurl.com/ ybakhwo9 (accessed 19 November 2018).

Valladares, L. (2010) 'Educação e mobilidade social nas favelas do Rio de Janeiro: O caso dos universitários (graduandos e graduados) das favelas'. Dilemas: Revista de Estudos de Conflito e Controle Social, 2 (5-6), 153-72.

van Zanten, A., Ball, S.J. and Darchy-Koechlin, B. (eds) (2015) World Yearbook of Education 2015: Elites, privilege and excellence: The national and global redefinition of educational advantage. London: Routledge.

Waters, J. and Brooks, R. (2012) 'Transnational spaces, international students: Emergent perspectives on educational mobilities'. In Brooks, R., Fuller, A. and Waters, J. (eds) Changing Spaces of Education: New perspectives on the nature of learning. London: Routledge, 21-38.

Wimmer, A. and Glick Schiller, N. (2003) 'Methodological nationalism, the social sciences, and the study of migration: An essay in historical epistemology'. International Migration Review, 37 (3), 576-610.

Ystanes, M. (2018) '\#sosfavelas: Digital representations of violence and inequality in Rio de Janeiro'. In Ystanes, M. and Strønen, I.Å. (eds) The Social Life of Economic Inequalities in Contemporary Latin America: Decades of change. Cham: Palgrave Macmillan, 81-105. 